\title{
Perancangan Sistem Rekomendasi Apotek di Wilayah Kota Singaraja
}

\section{Designing Recommending Systems of Pharmacy in City Area of Singaraja}

\author{
Komang Ananta Wijaya ${ }^{1}$, Ni Made Kemara Sujiana ${ }^{2}$, Ida Bagus Wikrantha Punarbawa ${ }^{3}$ \\ 1,2,3 Politeknik Kesehatan Kartini Bali \\ Jalan Piranha No. 2 Pegok Sesetan, Denpasar, 80223 \\ *e-mail korespondensi: ananta@politeknikkesehatankartinibali.ac.id
}

\begin{abstract}
Abstrak
Singaraja merupakan salah satu kota yang terletak di wilayah Bali Utara. Wilayah Kota Singaraja khususnya banyak terdapat apotek-apotek yang berbeda-beda. Sangat membingungkan jika ingin mencari apotek terdekat dari tempat tinggal, dan banyak masyarakat juga tidak tahu alamat apotek tersebut serta kelengkapan obat dan fasilitas kesehatan yang tersedia. Oleh sebab itu, maka dengan sistem LBS yang memanfaatkan teknologi GPS, dengan mudah orang-orang atau pengguna dapat mengetahui posisinya dan tempat-tempat tertentu, dimana tempat yang dibahas pada penelitian ini adalah Apotek di Wilayaha Kota Singaraja. Apotek merupakan sebuah tempat atau sarana yang digunakan untuk melakukan pelayanan kesehatan, apotek juga digunakan sebagai tempat meramu, menyediakan dan menyalurkan obat-obatan baik eceran atau dengan resep dokter. Rancangan sistem ini akan bekerja dengan menggunakan metode kolaboratif. Selain metode tersebut, sistem ini menggunakan Location-Based Service (LBS) yang memanfaatkan teknologi Global Positioning System (GPS) dalam pengaplikasiannya, maka pengguna dapat mengetahui posisinya serta pengguna dapat menentukan dan mencari apotek baik itu tempat yang jauh maupun dekat. Sistem ini berjalan pada perangkat mobile android. Dengan adanya rancangan sistem ini, maka diharapkan kedepannya dapat mempermudah masyarakat dalam pencarian apotek terdekat dari lokasinya berada, kelengkapan fasilitas dan sarana kesehatan yang disediakan.
\end{abstract}

Keywords: Sistem Rekomendasi, Apotek, Singaraja, Location-Based Service (LBS), Global Positioning System (GPS)

\begin{abstract}
Singaraja is a city located in North Bali. Singaraja City area in particular has many different pharmacies. It is very confusing if you want to find the nearest pharmacy from where you live, and many people also don't know the address of the pharmacy and the completeness of the drugs and health facilities available. Therefore, with the LBS system that utilizes GPS technology, people or users can easily find out their position and certain places, where the place discussed in this study is the Pharmacy in the City of Singaraja. Pharmacy is a place or facility used to provide health services, pharmacies are also used as a place for gathering, providing and distributing medicines either retail or with a doctor's prescription. The design of this system will work using a collaborative method. In addition to these methods, this system uses Location-Based Service (LBS) which utilizes Global Positioning System (GPS) technology in its application, so users can find out their position and users can determine and search for pharmacies, both far and near. This system runs on android mobile devices. With the design of this system, it is hoped that in the future it can make it easier for the community to find the nearest pharmacy from its location, complete the facilities and health facilities provided.
\end{abstract}

Keywords: Recommending Systems, Pharmacy, Singaraja, Location-Based Service (LBS), Global Positioning System (GPS) 


\section{PENDAHULUAN}

Apotek merupakan sebuah tempat atau sarana yang digunakan untuk melakukan pelayanan kesehatan, apotek juga digunakan sebagai tempat meramu, menyediakan dan menyalurkan obat-obatan baik eceran atau dengan resep dokter. Selain obat-obatan, apotek juga menjual berbagai peralatan farmasi lainnya yang dibutuhkan oleh masyarakat umum.

Pada setiap daerah terdapat berbagai macam apotek dengan nama, ketersediaan obat, peralatan farmasi, fasilitas yang berbeda-beda. Bahkan apotek tidak hanya bisa di temui di daerah kota, namun sudah masuk ke wilayahwilayah pedesaan dan tentu saja dengan ketersediaan obat, peralatan farmasi dan fasilitas kesehatan yang lebih minim. Seperti halnya ada apotek yang hanya menjual obat dan perlatan farmasi yang jumlahnya lebih sedikit, ada juga apotek yang di dalamnya terdapat praktek apoteker, bahkan ada apotek yang lebih lengkap dimana disediakannya praktik-praktik dokter umum, hingga praktik dokter spesialis.

Singaraja merupakan salah satu kota yang terletak di wilayah Bali Utara. Wilayah Kota Singaraja khususnya banyak terdapat atau tersedia apotek-apotek yang berbeda-beda. Sangat membingungkan jika ingin mencari apotek terdekat dari tempat tinggal, dan banyak masyarakat juga tidak tahu alamat apotek tersebut serta kelengkapan obat dan fasilitas kesehatan yang tersedia. Oleh sebab itu, maka dengan sistem $L B S$ yang memanfaatkan teknologi GPS, dengan mudah orang-orang atau pengguna dapat mengetahui posisinya dan tempat-tempat tertentu, dimana tempat yang dibahas pada penelitian ini adalah Apotek di Wilayaha Kota Singaraja.

Sistem rekomendasi sangat diperlukan saat ini, karena dengan adanya sistem ini dapat membantu pengguna dalam hal untuk membandingkan beberapa objek (apotek, tempat wisata, dan lain sebagainya). Sistem ini bekerja dengan cara mengumpulkan objek-objek terbaik. Kemudian sistem akan menyaring objek-objek tersebut dan mencari objek yang paling mirip dengan objek yang dicari oleh pengguna. Kemudian sistem akan menampilkan lokasi objek dan posisi pengguna di dalam peta, sehingga pengguna dapat mengetahui letak dari objek yang dicari (Bartolini, et al., 2016).

Sebagian besar perangkat mobile saat ini sudah dilengkapi dengan GPS, GPS sangat berguna untuk menentukan posisi saat berada di luar daerah. GPS tidak berlaku jika pengguna berada di dalam ruangan, maka radio-frequency identification (RFID) yang akan menggantikan sebagai penentu posisi pengguna (Wang, Chen, \& Deng, 2015).

Location-Based System (LBS) adalah sebuah sistem yang memanfaatkan teknologi Global Positioning Service (GPS). Sebelumnya telah dilakukan sebuah penelitian tentang Spatial-Temporal Behavior (STB) dari Backpackers di Beijing berdasarkan Lintasan yang dilalui. Penelitian ini mengumpulkan datadata yang akan mendukung kinerja $L B S$ kedepannya di kota-kota lain selain Beijing. $L B S$ berkembang dengan cepat karena teknologi berikut: spatial positioning technologies, geographical information system (GIS) technologies and wireless communication technologies; Posisi adalah inti, GIS adalah platform, dan komunikasi nirkabel adalah media. Kita bisa mendapatkan lokasi spasial dari suatu entitas melalui spatial positioning technologies, kemudian menggunakan GIS sebagai platform untuk mengelola dan menganalisis informasi geografis untuk memenuhi kebutuhan pengguna, akhirnya layanan dikirim ke pengguna melalui media komunikasi nirkabel. Penelitian ini mengguna 1.078 sampel data lintasan untuk mempelajari STB dari para Backpackers di Beijing. Penelitian ini menyimpulkan bahwa lintasan merupakan sumber yang baik untuk melihat STB dari para Backpackers (Huang \& Xia, 2016).

Layanan Berbasis Lokasi (LBS) adalah layanan informasi dan hiburan, dapat diakses dengan perangkat mobile melalui jaringan seluler dan memanfaatkan kemampuan untuk menentukan posisi geografis penggunaan perangkat selular. Layanan $L B S$ dapat digunakan dalam berbagai konteks, seperti Kesehatan, pekerjaan, kehidupan pribadi, dan lain-lain. $L B S$ mencakup layanan untuk mengidentifikasi lokasi seseorang atau objek, seperti menemukan mesin ATM Bank terdekat atau mencari lokasi teman. Layanan LBS termasuk pelacakan paket dan layanan pelacakan kendaraan (Kushwaha \& Kushwaha, 2011).

Global Positioning System (GPS) adalah sistem navigasi berbasis satelit yang terdiri atas 24 jaringan satelit yang ditempatkan pada orbit oleh Departemen Pertahanan AS. GPS awalnya ditujukan untuk aplikasi militer, tetapi di tahun 1980, pemerintah membuat sistem tersedia untuk digunakan sipil. GPS bekerja dalam kondisi cuaca, di mana saja di dunia, 24 jam sehari. Tidak ada biaya berlangganan atau biaya setup untuk menggunakan GPS (GARMIN, 1996-2016). 
Android adalah sistem operasi bersifat open source berbasis Linux dirancang untuk perangkat seluler layar sentuh seperti telepon pintar dan komputer tablet. Android awalnya dikembangkan oleh Android, Inc., dengan dukungan finansial dari Google, yang kemudian membelinya pada tahun 2005. Sistem operasi ini dirilis secara resmi pada tahun 2007, bersamaan dengan didirikannya Open Ponsel Android pertama mulai dijual pada bulan Oktober 2008. Kemudian untuk mengembangkan Android, dibentuklah Open Handset Alliance yang merupakan konsorsium dari 34 perusahaan perangkat keras, perangkat lunak dan telekomunikasi (Surahman \& Setiawan, 2017).

\section{METODE PENELITIAN}

\section{Rancangan Skema Metode Penelitian}

Rancangan skema penelitian adalah sebuah metode yang digunakan oleh peneliti sebagai acuan untuk melakukan penelitian agar sesuai dengan tahapan yang telah disusun, serta menampilkan kontribusi yang diberikan dalam penelitian yang dilakukan (Gambar 1).

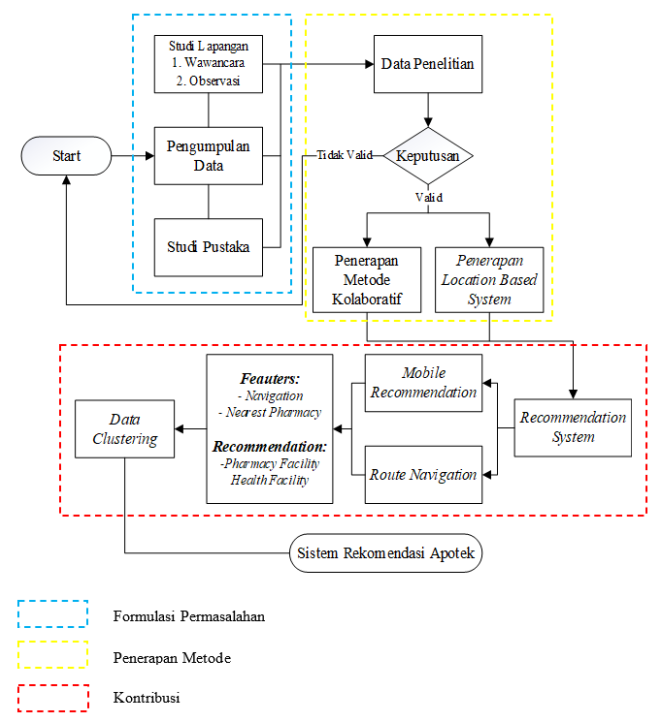

Gambar 1. Rancang Skema Penelitian

\section{Collaborative Filtering (CF)}

Collaborative filtering melakukan penyaringan data berdasarkan kemiripan karakteristik konsumen sehingga mampu memberikan informasi yang baru kepada konsumen karena sistem memberikan informasi berdasarkan pola satu kelompok konsumen yang hampir sama. Perbedaan minat pada beberapa anggota kelompok menjadikan sumber informasi baru yang mungkin bermanfaat bagi anggota kelompok lainnya (Uyun, Fahrurrozi, \& Mulyanto, 2011).
Pada pendekatan collaborative filtering, dilakukan perhitungan jarak antar rating setiap pengguna dengan pengguna yang akan diberikan rekomendasi. Dalam perhitungan jarak dapat digunakan Euclidean Distance dengan ruang dimensi n (Rumus (1)):

$$
d\left(\left[x_{1}, x_{2}, \ldots x_{n}\right],\left[y_{1}, y_{2}, \ldots y_{n}\right]\right)=\sqrt{\sum_{i=1}^{n}\left(x_{i}-y_{i}\right)^{2}}
$$

Dimana, $d(x, y)$ adalah Euclidean Distance dari pengguna $x$ dan dan pengguna $y$ (pennguna yang akan diberikan rekomendasi). $x i$ adalah nilai rating pengguna $x$ terhadap item $i$, dan $y i$ adalah nilai rating pengguna $y$ terhadap item $i$.

Setelah didapatkan nilai Euclidean Distance, maka selanjutnya dihitung nilai kemiripannya berdasarkan hasil dari persamaan (1). Berikut rumusnya:

$$
\operatorname{Sim}(x, y)=\frac{1}{1+d(x, y)}
$$

Dimana, $\operatorname{Sim}(x, y)$ adalah nilai kemiripan rating antara pengguna $x$ dan pengguna $y$. sedangkan $d(x, y)$ adalah nilai Euclidean Distance rating antara pengguna $x$ dan $y$.

\section{HASIL DAN PEMBAHASAN}

\section{Perspektif Produk}

SIRASI (Sistem Rekomendasi Apotek Singaraja) merupakan sebuah perangkat lunak yang dikembangkan guna membantu pengguna dalam proses pencarian rekomendasi apotek terlengkap dan terdekat di wilayah Kota Singaraja khususnya terdekat dan terlengkap dari posisi si pengguna. Aplikasi ini menggunakan metode Collaborative Filtering, Location Based Service (LBS), serta menggunakan Google Maps untuk menampilkan lokasi Apotek serta Navigasi atau rute menuju apotek yang telah direkomendasikan.

Sistem rekomendasi ini berjalan pada perangkat mobile dengan sistem operasi Android minmal versi 7.0 dengan menggunakan bahasa pemrograman $J A V A$. Pengguna akan berinteraksi dengan sistem melalui antarmuka GUI (Graphical User Interface) pada perangkat mobile.

\section{Kebutuhan fungsionalitas Perangkat Lunak}

Use case diagram merupakan perancangan perangkat lunak yang menggambarkan hubungan 
yang terjadi antara aktor dengan fungsi aplikasi. Pada gambar 2, bisa dilihat bahwa pengguna sebagai aktor dan fungsi aplikasi terdiri dari 4 fungsi yaitu, menampilkan Pencarian Rekomendasi, menampilkan Ganti bahasa, menampilkan Cara Penggunaan dan menampilkan tentang.

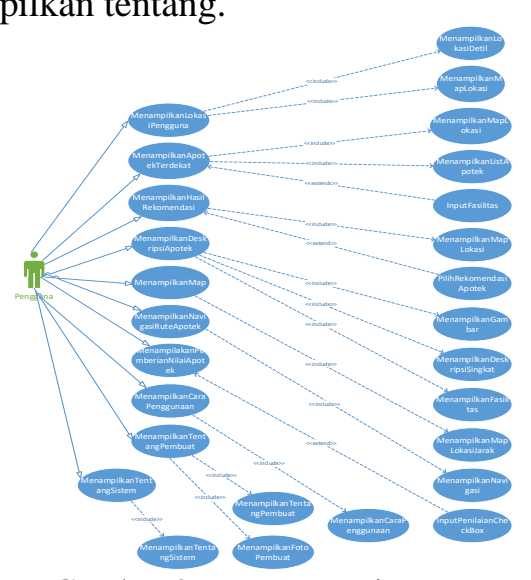

Gambar 2. Use Case Diagram

Pada use case diagram di atas (gambar 2) menjelaskan tentang bagaimana pengguna dapat mengakses perangkat lunak SIRASI diantaranya menampilkan pencarian rekomendasi, menampilkan lokasi pengguna berada, menampilkan apotek terdekat, menampilkan hasil rekomendasi, menampilkan deskripsi singkat apotek rekomendasi, menampilkan jarak pengguna ke apotek yang direkomendasikan (dalam Maps), menampilkan Route Navigation dari tempat pengguna menuju tempat yang direkomendasikan (dalam Maps), menampilkan cara penggunaan perangkat lunak SIRASI, menampilkan Tentang pembuat aplikasi atau perangkat lunak SIRASI, dan menampilkan tentang aplikasi atau perangkat lunak SIRASI.

\section{Fungsi Produk dan Rancangan Antarmuka}

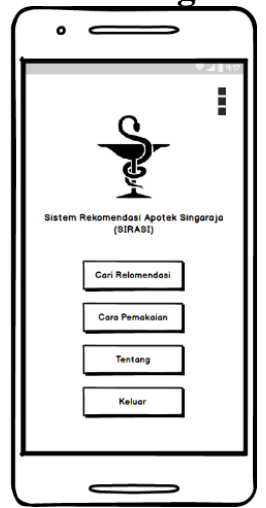

Gambar 3. Halaman Utama Aplikasi SIRASI

Fungsi yang terdapat pada Aplikasi SIRASI ini adalah sebagai berikut:

\section{Fungsi Ganti Bahasa}

Merupakan sebuah fungsi yang dapat digunakan oleh user dalam mengganti Bahasa pada aplikasi, baik itu dari bahasa Indonesia ke Inggris (IND $\rightarrow$ ENG) ataupun sebalikkanya $(\mathrm{ENG} \rightarrow \mathrm{IND})$.

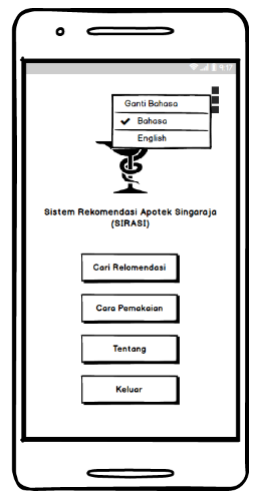

Gambar 4. Halaman Ganti Bahasa

\section{Fungsi Pencarian Rekomendasai}

Merupakan fungsi yang dapat digunakan oleh pengguna dalam mencari rekomendasi Apotek terdekat dari posisi pengguna saat menggunakan aplikasi

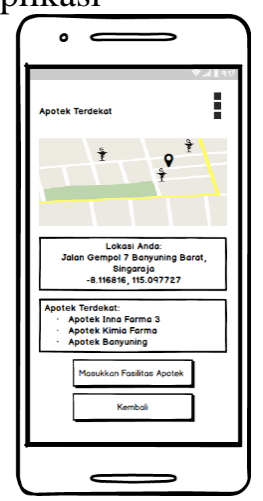

Gambar 5. Halaman Apotek Terdekat

\section{Fungsi Menampilkan Deskripsi Singkat Apotek Rekomendasi}

Fungsi yang akan menampilkan deskripsi singkat rekomendasi apotek yang didapatkan berikut dengan gambar dan profil singkat apotek tersebut.

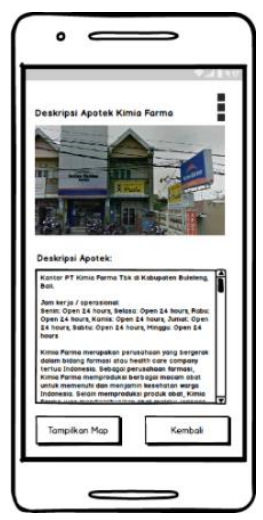

Gambar 6. Halaman Deskripsi Singkat Apotek Rekomendasi 


\section{Fungsi Menampilkan Lokasi Apotek Rekomendasi dalam Map}

Fungsi yang akan menampilkan posisi atau letak rekomendasi apotek yang telah didapatkan dalam map, dimana map disini yang dimaksud adalah Google Maps.

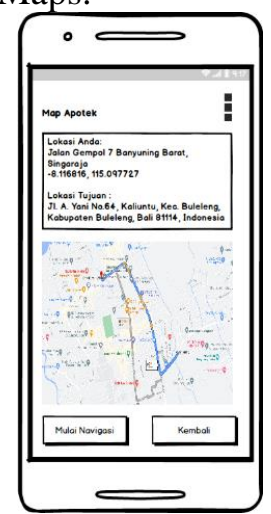

Gambar 7. Halaman Lokasi Apotek Rekomendasi dalam Map

\section{Fungsi Menampilkan Navigasi atau Rute Menuju Apotek Rekomendasi}

Fungsi yang akan menampilkan arah atau rute terdekat jika pengguna ingin menuju ke apotek hasil rekomendasi yang didapatkan.

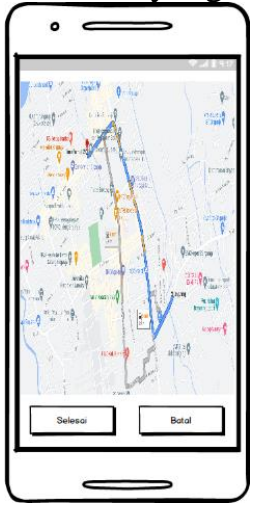

Gambar 8. Halaman Navigasi

\section{Fungsi Cara Penggunaan Aplikasi}

Merupakan fungsi yang akan menampilkan cara pemakaian atau penggunaan system atau aplikasi SIRASI kepada pengguna.

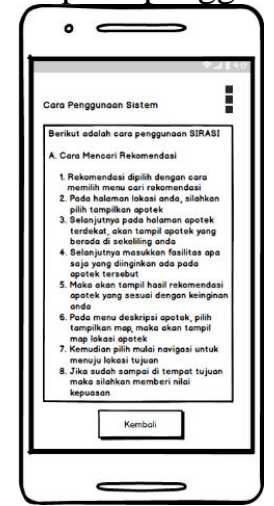

Gambar 9. Halaman Cara Pengunaan Aplikasi

\section{Fungsi Tentang Aplikasi}

Merupakan fungsi yang akan menampilakan informasi kepada pengguna tentang pembuat aplikasi dan informasi tentang aplikasi SIRASI.

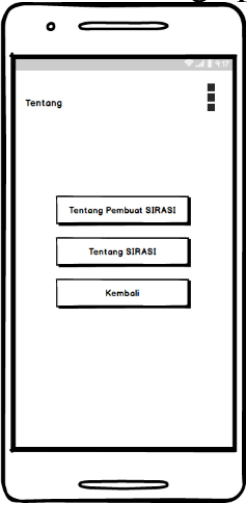

Gambar 10. Halaman Tentang

Fungsi Informasi atau Data Pembuat Aplikasi

Fungsi yang menampilkan profil atau data diri pembuat aplikais SIRASI

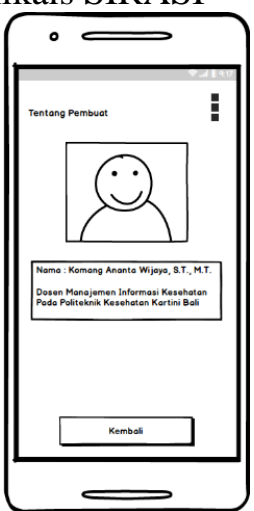

Gambar 11. Halaman Tentang Pembuat

\section{Fungsi Informasi Aplikasi}

Fugsi yang akan menampilkan informasi tentang aplikasi SIRASI.

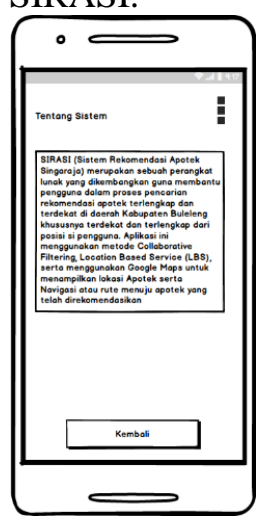

Gambar 12. Halaman Tentang Aplikasi

\section{SIMPULAN}

Berdasarkan hasil dan pembahasan yang telah dipaparkan, maka dapat ditarik kesimpulan bahwa perancangan sistem rekomendasi apotek 
di wilayah Kota Singaraja diharapkan kedepannya dapat dituangkan kedalam aplikasi mobile yang dapat membantu orang-orang dari segala kalangan, baik itu orang umum ataupun orang asli Singaraja untuk mengetahui serta mencari rekomendasi lokasi apotek yang terbaik di daerah Kota Singaraja dengan mudah.

\section{DAFTAR RUJUKAN}

Bartolini, I., Moscato, V., Pensa, R. G., Penta, A., Picariello, A., Sansone, C., \& Sapino, M. L. (2016). Recommending multimedia visiting paths in cultural heritage applications. Multimedia Tools and Applications, V(7), 3813-3842.

GARMIN. (1996-2016). Dipetik June 19, 2021, dari http://www8.garmin.com/aboutGPS/

Huang, Q., \& Xia, L. (2016). Inspection of Spatial-Temporal Behavior of Backpackers in Beijing Based on Trajectory. Wireless Pers Commun(87), 1337-1356.

Kushwaha, A., \& Kushwaha, V. (2011, March). Location Based Services using Android Mobile Operating System. International Journal of Advances in Engineering \& Technology, I(1), 14-20.

Surahman, S., \& Setiawan, E. B. (2017, Juni). Aplikasi Mobile Driver Online Berbasis Android Untuk Perusahaan Rental Kendaraan. ULTIMA InfoSys, VIII(1), 35-42. doi:ISSN 2085-4579

Uyun, S., Fahrurrozi, I., \& Mulyanto, A. (2011). Item Collaborative Filtering untuk Rekomendasi Pembelian Buku secara Online. JUSI, I(1), 63-70.

Wang, C.-S., Chen, C.-L., \& Deng, D.-J. (2015). P2P-based mobile navigation system with location service. Peer-to-Peer Netw. Appl., VIII, 22-31. 